\title{
O ksztaltowaniu się ustroju Królestwa Polskiego w 1831 roku
}

Sejm, który zebrał się po Nocy Listopadowej, nie miał charakteru konstytuanty ${ }^{1}$, niekiedy nawet unikał takiego samookreślenia swojej pozycji ${ }^{2}$, ale mimo to od samego początku rozpoczęło się kształtowanie przezeń nowego ustroju Królestwa Polskiego. Jaki charakter przybrał ustrój państwa polskiego, walczącego z Rosją o niepodległość? To temat rzadko poruszany w nowszej literaturze historycznoprawnej ${ }^{3}$, a z pewnością wart refleksji. Spróbuję także zastanowić się, czy zmiany w konstytucji Królestwa Polskiego, dokonywane przez Sejm w 1831 r., oznaczały powstanie całkowicie oryginalnego ustroju, czy jednak korzystano tu z pewnych rozwiązań z przeszłości? Z jakich i jakim ewentualnie poddawano je modyfikacjom?

I. W styczniu $1831 \mathrm{r}$. w komisjach sejmowych złożono wnioski w sprawie detronizacji. Proklamacje wojenne feldmarszałka Iwana Dybicza, dowódcy wkraczającej do Królestwa armii rosyjskiej, znane posłom od 23 stycznia, przyspieszyły prace nad ich rozpatrzeniem. 25 stycznia głos zabrał marszałek

${ }^{1}$ S. Barzykowski (Historya powstania listopadowego, Poznań 1884, t. III, s. 299) pisał: „Rząd obecny uważał Sejm tylko za Sejm prawodawczy i część władzy królewskiej, skutkiem wypadków piastujący, ale nie za Sejm ustawodawczy, ku temu trzeba było nowych wyborów, szczególnych upoważnień, aby prawo zasadnicze mógł nadać".

${ }^{2} \mathrm{~W}$ trakcie prac legislacyjnych w Senacie nad projektem uchwały w sprawie reprezentacji Litwy i Wołynia skreślony został art. 9, stanowiący, że reprezentanci ziem litewsko-ruskich wraz z Sejmem Królestwa mieli stanowić Sejm nadzwyczajny, którego celem „będzie obmyślenie najskuteczniejszych środków oswobodzenia wspólnej Ojczyzny, połączenie w jedno rozdzielnych braci (...) na koniec Sejm ten ustanowi stałe prawo o wyborach, o składzie i atrybucyach obu Izb Sejmu, podług którego przyszły Sejm zwyczajny wybranym i zwołanym być ma. Gdyby w ciągu tego nadzwyczajnego Sejmu wypadła potrzeba wyboru dynastyi, Sejm ten przystąpi do niego i ułoży warunki, pod którymi Król panować ma, czyli położy zasady przyszłej konstytucyi lub nawet całkowitą ułoży" (Dyaryusz Sejmu z r. 1830 i 1831, wydał M. Rostworowski, Kraków 1909, t. III, s. 571, przypis). Izba Poselska nie przywróciła tego przepisu, co oznacza, że Sejm świadomie zrezygnował z nadania sobie kompetencji stanowienia nowej konstytucji.

${ }^{3}$ Wyjątek stanowi tu praca Z. Gołby, Rozwój władz Królestwa Polskiego w okresie powstania listopadowego, Wrocław 1971. 
Władysław Ostrowski i zaproponował zdetronizowanie Mikołaja, po czym na środek izby wybiegł poseł Jan Ledóchowski i zawołał:

„Wyrzeczmy zgodnie: nie ma Mikołaja! A Mikołaj przestanie panować. Słowa te powtórzyli niektórzy z członków sejmu. Obecni widze zawołali: nie ma Mikołaja - niech żyje naród!, dopełnione zostało zbyt ważne a niebezpieczne dzieło, z radością zapalonych, z bólem rozsądnych i z podziwem powszechnem"”.

Inny deputowany wspominał, że marszałek akt detronizacyjny „szturmem przeprowadził” przez Sejm, gdyż „w istocie nie uchwalono go, bo go ani dyskutowano, ani według form przepisanych nie wniesiono, ani nad nim nie głosowano"s.

Potem nastąpiło podpisywanie uchwały detronizacyjnej przez obecnych posłów i senatorów. Nacisk był tak duży, iż jeden z senatorów napisał w swoich wspomnieniach, że „każdy był przekonany, że gdy nie poddamy się tej przemocy, nastąpiłby przelew krwi a nawet obalenie władzy sejmu"6. Akt detronizacji podpisał również ks. Adam Czartoryski, chociaż jednocześnie miał powiedzieć w kierunku Władysława i Antoniego Ostrowskich: „Zgubiliście Polskę"7. Tylko dlaczego zabrakło mu odwagi cywilnej, żeby przeciwstawić się tej decyzji? Uogólniając Franciszek Wężyk stwierdził: „Gdy kto zapyta, jakiej winie akt ten niewczesny przypisać? Odpowiem śmiało: brakowi obywatelskiej odwagi"s.

Uchwała dość niejasno formułowała, czy szło o detronizację tylko króla Mikołaja, czy o odsunięcie od tronu polskiego całej dynastii Romanowych, ale przyjęło się uważać, iż detronizacja tyczyła tylko osoby aktualnego panującego ${ }^{9}$, chociaż próby namówienia Habsburgów do objęcia tronu w Warsza-

${ }^{4}$ F. Wężyk, Powstanie Królestwa Polskiego w roku 1830 i 1831, Kraków 1895, s. 56-57. L. Dembowski (Moje wspomnienia, Petersburg 1898, t. II, s. 163) zanotował na temat okrzyku posła J. Ledóchowskiego, że ,wszyscy senatorowie i posłowie w milczeniu a nawet trwodze słyszeli podobne słowa, galerye zaś z zapałem wniosek ten popierały". Obszerną relację przedstawia S. Barzykowski, Historya..., t. II, s. 162-165 oraz szczególnie S. Ziółek, Sejm Królestwa Polskiego w okresie powstania listopadowego 1830-1831, Warszawa 2007, s. 107-128; por. też Dyaryusz..., Kraków 1907, t. I, s. 243-244.

${ }^{5}$ L. Dembowski, Moje wspomnienia..., s. 161.

${ }^{6}$ Ibidem, s. 163.

${ }^{7}$ Ibidem.

${ }^{8}$ F. Wężyk, Powstanie..., s. 59.

${ }^{9}$ Senator F. Wężyk twierdził 27 stycznia, że „bynajmniej nie wyrzekliśmy, że usuwany całą dynastyę R o ma n o w y c h od konkurencyi od tronu", a jedynie Mikołaja, na co replikował natychmiast poseł J. Ledóchowski, że „całą dynastyę usunęliśmy od niego (tronu - L. M.)” (Dyaryusz..., s. 300, 301). W literaturze z pewną niechęcią konstatował fakt złożenia z tronu jedynie aktualnie panującego W. Zajewski, Powstanie listopadowe 1830-1831, [w:] S. Kieniewicz, A. Zahorski, W. Zajewski, Trzy powstania narodowe, Warszawa 1997, s. 193. Wcześniej Z. Gołba, Rozwój..., s. 117 pisał, że uchwała „w formie wynikowej stanowi o detronizacji Mikołaja”, ale nic nie ma tam o odsunięciu dynastii Romanowych w ogóle. 
wie ${ }^{10}$ mogłyby świadczyć o czymś innym. Z całą pewnością jednak uchwała, nic nie mówiąc o zmianie formy państwa na republikę, utrzymywała monarchię ${ }^{11}$. Świadczyłoby o tym także stwierdzenie, że „Naród (...) Polski, na sejm zebrany, (...) ma prawo temu koronę polską oddać, którego godnym jej uzna".

Władysław Bortnowski oceniał, że akt detronizacji „wynikał z przyjęcia przez większość herbowych (...) zasady, że szlachecki sejm posiada pełne prawo dysponowania tronem polskim" "2; tylko z czego takie prawo wynikało? W konstytucji Królestwa Polskiego z 1815 r. ${ }^{13}$ nic na ten temat się nie mówiło, zaś w Akcie końcowym przyjętym w Wiedniu 9 czerwca 1815 r. stanowiono, że Królestwo Polskie „Ma być związane z nim (Cesarstwem Rosyjskim) przez swą konstytucyę i na wieczność włączone w osobach JCM Cesarza Wszechrosji, jego następców i dziedziców". W rezultacie uchwała detronizacyjna mogła być jedynie przejawem samookreślenia kompetencji Sejmu, chociaż po raz pierwszy z taką sytuacją mieliśmy do czynienia nieco wcześniej; mowa o uchwale o sposobie początkowania, obradowania, dyskutowania i przyjmowania projektów z 22 stycznia $1831 \mathrm{r}^{14}$, gdzie z naruszeniem konstytucji z 1815 r. uregulowano sposób stanowienia aktów prawnych przez Sejm.

Złożenie z tronu Mikołaja, a tym bardziej odsunięcie od władzy w Warszawie przedstawicieli rosyjskiego domu panującego, bo rzecz mogła rodzić spory, stwarzało problem wykonywania władzy publicznej do momentu powołania nowego monarchy. W jaki sposób zostało to rozwiązane w Królestwie Polskim w 1831 r.?

${ }^{10}$ K. Koźmian (Pamiętniki, Wrocław-Warszawa-Kraków-Gdańsk 1972, t. III, s. 300) wspominał, że chodziło o to, aby zostawić ,tron pro vacante jako środek przywabienia do niego Austrii”. Tak samo W. Tokarz (Polska, jej dzieje i kultura, Warszawa 1934, t. III, s. 162): „Książę Adam Czartoryski oraz minister spraw zagranicznych Gustaw Małachowski liczyli przede wszystkim na Austrię w swych rozmowach z konsulem austriackim w Warszawie zaręczali, że niepodległa Polska oprze się całkowicie na Austrii, stanie się rynkiem zbytu dla jej produktów przemysłowych; w kołach sejmowych myślano poważnie o ofiarowaniu korony polskiej arcyksięciu Karolowi lub księciu Reichstadt”, czyli synowi Napoleona. Ks. Klemens von Metternich w instrukcji dla ambasadora Austrii w Rosji z 4 lutego 1831 r. propozycję Warszawy powołania na tron arcyksięcia Karola określił jako ,śmieszne, nieudolne, a w ogóle zbrodnicze, słowem - typowy okaz polskiej lekkomyślności” (cyt. za W. Zajewski, Powstanie listopadowe..., s. 245).

${ }^{11}$ Innego zdania byli J. Dutkiewicz i W. Zajewski (O niektórych aspektach postęowego nurtu ideologicznego w powstaniu listopadowym, „Czasopismo Prawno-Historyczne”, 1957, z. 1, s. 301), którzy twierdzili, że Królestwo w okresie od 25 stycznia do 8 lutego miało republikańską formę państwa. Z tezą tą polemizował W. Rostocki, Jeszcze w sprawie „Elementów postępowych w ideologii politycznej i w ustroju powstania listopadowego”, „Czasopismo Prawno-Historyczne”, 1957, z. 1, s. 316-317.

${ }^{12}$ W. Bortnowski, W sprawie aktu detronizacji Romanowych ze stycznia 1831 r., „Przegląd Historyczny”, 1959, nr 4, s. 862-863.

${ }^{13}$ Dziennik Praw Królestwa Polskiego, t. I, s. 3-102.

${ }^{14}$ Dyaryusz..., t. I, s. 343-344. 
II. Skoro nie zmieniono formy państwa na republikańską, to uchwała detronizacyjna wymagała szybkiego powołania nowego monarchy bądź też, gdyby na to się nie zdecydowano, określenia sposobu, w jaki miała być sprawowana władza w Królestwie w okresie bezkrólewia. Kwestię tę rozstrzygnęła uchwała o rządzie z 29 stycznia 1831 r. ${ }^{15}$, która w preambule wyraźnie powoływała się na konieczność uregulowania na nowo zagadnień z zakresu ustroju państwa, w sytuacji gdy „stosunki polityczne z cesarzem rosyjskim zostały zerwane".

Art. 1 derogował Tytuł I oraz rozdz. II Tytułu III ustawy konstytucyjnej Królestwa, a także mające $\mathrm{z}$ nimi związek inne przepisy umieszczone w samej konstytucji, statutach organicznych, prawach i postanowieniach, ponadto $\mathrm{z}$ art. 108, dotyczącego składu Senatu, wykluczono „książąt z krwi cesarsko-królewskiej”. W ten sposób uchylono wszystkie postanowienia mówiące o węźle publicznoprawnym, jaki od 1815 r. istniał między Królestwem a Cesarstwem. Skoro został zlikwidowany dualizm rosyjsko-polski, czyli detronizacja tyczyła nie tylko Mikołaja, a dynastii Romanowych, to w efekcie niepotrzebne już były takie instytucje prawne jak namiestnik czy regencja.

Art. 2 stwierdzał:

„Wszelkie inne przepisy tejże Ustawy konstytucyjnej (chodzi o konstytucję z 1815 r. - L. M.) oraz mające z niemi związek przepisy, statutami organicznemi i innemi prawami i postanowieniami objęte, utrzymują się w swojej nienaruszalnej mocy, o ile przez uchwały niniejszego sejmu nadzwyczajnego niezmienionemi lub uchylonemi nie były i jeszcze zmienionemi lub uchylonemi nie zostaną".

W sumie Izby wyraźnie stanowiły, że wszelkie inne przepisy prawne będą nadal obowiązywać, jeśli taka jest (bądź będzie) wola nowego ustawodawcy konstytucyjnego, który określi też zakres stosowania tych przypisów.

Poza przepisami uchylonymi, które właśnie wymieniłem, uchwała zawierała również przepisy, które zostają czasowo zawieszone „w czasie teraźniejszego bezkrólewia". W art. $3 \mathrm{w}$ takim charakterze wymieniono rozdz. I, III i IV Tytułu III, z tym że obowiązywać miały nadal art. 78, 79, 80 i 82. Czasowo zawieszone byłyby zatem postanowienia dotyczące króla, namiestnika i Rady Stanu ${ }^{16}$ oraz wydziałów rządowych. Utrzymane zaś w mocy przepisy stanowiły o istnieniu izby obrachunkowej (art. 78), konieczności ustanowienia statutu organicznego w celu oznaczenia składu i atrybucji Komisji Oświecenia

${ }^{15}$ Ibidem..., t. I, s. 365-368. O pracach nad tą uchwałą zob. S. Ziółek, Sejm Królestwa Polskiego..., s. 130-134, zaś w części dotyczącej Naczelnego Wodza w szczególności W. Rostocki, Wtadza Wodzów Naczelnych w powstaniu listopadowym. Studium historycznoprawne, Wrocław 1955, s. 64-68.

${ }^{16}$ Instytucja Rady Stanu na nowo została uregulowana uchwałą o Radzie Stanu z 30 sierpnia 1831 r. (por. Dyaryusz..., Kraków 1912, t. VI, s. 479-481), ale nie miało to wpływu na istniejący system władzy publicznej. 
Publicznego, a także sądownictwa (art. 79), Komisje Spraw Wewnętrznych, Wojny i Skarbu miały się składać z ministra i radców stanu, dyrektorów generalnych ,podług rozporządzeń statutów organicznych” (art. 80) i wreszcie „Ministrowie naczelnicy wydziałów, tudzież członki komisji rządowych odpowiadają i podległymi są sądom sejmowym za każde naruszenie ustawy konstytucyjnej, praw i postanowień królewskich, którego by się dopuścili” (art. 82).

Dodatkowo w art. 3 stanowiono jeszcze, że ,aż do wyboru nowego króla zawieszają się w swej mocy wszelkie artykuły, gdzie osoba króla i jego familia lub ich prerogatywy są wzmiankowane", a w to miejsce wchodzą przepisy zawarte w niniejszej uchwale.

Dla wzmocnienia pozycji Sejmu zasadnicze znaczenie miał art. 4, który, co prawda, stanowił, że Rządowi Narodowemu powierzone jest sprawowanie królewskiej władzy konstytucyjnej, ale tylko w zakresie określonym przez uchwałę, ,reszta władzy takowej zostaje przy obu izbach”. Innymi słowy, domniemanie kompetencji w tym przypadku służyło Sejmowi, do rządu należało wykonywanie tylko wyraźnie określonych uprawnień przejętych po monarsze, przy czym najważniejsze $\mathrm{z}$ nich pozostawały w gestii Izb. Tak było choćby w przypadku prawa do zawarcia traktatu o pokoju, co wynikało z brzmienia art. 9, albo możliwości ułaskawienia w przypadku zbrodni stanu (art. 12).

O pozycji ustrojowej Rządu Narodowego będzie jeszcze dalej mowa, ale już tu należy stwierdzić, że organ ten w istotny sposób zależny był od Sejmu; to samo, chociaż w mniejszym stopniu, odnosiło się do Wodza Naczelnego.

Ale uchwała o rządzie z 29 stycznia 1831 r. nie tyle stanowiła o najwyższej pozycji Sejmu, ile wysuwała na plan pierwszy Izbę Poselską w nowym systemie władzy publicznej; zresztą podobną regulację zawierała już uchwała o sposobie początkowania, obradowania, dyskutowania i przyjmowania projektów z 22 stycznia $1831 \mathrm{r}$.

W art. 11 uchwały z 29 stycznia mówiło się, że „Sejm wybiera z podanych sobie przez senat, w podwójnej liczbie na każde miejsce, kandydatów", co oznacza, że to Izba Poselska decydowała teraz o składzie Senatu ${ }^{17}$, skoro posłowie i deputowani stanowili zgodnie z art. 109 konstytucji większość. Z kolei art. 3 uchwały z 22 stycznia stanowił, że projekt uchwały, który został odrzucony przez drugą izbę ,roztrząsany będzie w obu połączonych izbach, które względem przyjęcia lub odrzucenia onegoż ostatecznie i prostą większością głosów postanowią"18. Także i w tym przypadku oczywista była prze-

${ }^{17} \mathrm{~W}$ trakcie debaty deputowany Franciszek Wołowski zwrócił uwagę, że chcąc zachować dotychczasową pozycję Senatu, trzeba większości 2/3, a nie zwykłej Izb połączonych. Deputowany Jan Posturzyński trafnie dodawał: „Izba Poselska powinna być oddzielona od Senatorskiej, boby ta upadła prostą większością" (Dyaryusz..., t. I, s. 117-118, 124).

${ }^{18}$ L. Dembowski (Moje wspomnienia..., s. 151) słusznie zauważył: „Zdaje się, że byłoby właściwiej wyrzec, iż projekt, który nie otrzyma zatwierdzenia w jednej z Izb, może być powtórnie wniesiony z odmianami tych artykułów, które się stały powodem odrzucenia”. 
waga posłów i deputowanych nad senatorami. To samo można powiedzieć o rozwiązaniu przyjętym w art. 4 tej uchwały, gdzie była mowa, że ,wybór lub oddalenie osób, rząd składających, wypowiadanie wojny, ratyfikacje traktatów, które przedmioty nie mają przechodzić przez oddzielne izby, lecz zaraz do izb połączonych wnoszone i tamże ostatecznie załatwione być winny”.

Przewaga Izby Poselskiej nad Senatem na gruncie styczniowych uchwał Sejmu powodowała, iż z bikameralizmu, jaki cechował stosunki między obu Izbami w 1815 r., niewiele pozostało. W konsekwencji poseł Konstanty Swidziński twierdził nawet, że szło o to, ,,żeby Senat był zniesiony"19.

W uchwale detronizacyjnej z 25 stycznia, poprzedzającej ją o trzy dni uchwale o sposobie początkowania, obradowania, dyskutowania i przyjmowania projektów, a także uchwale o rządzie z 29 stycznia 1831 r. wyrażało się samookreślenie przez Sejm własnych kompetencji oraz określenie kompetencji przysługujących innym organom państwa. Kto posiada i wykonuje takie uprawnienia $-\mathrm{z}$ pewnością jest ustrojowym suwerenem. Próbą ustrojowopolitycznej legitymizacji tego rodzaju działań było odwołanie się przez parlament do realizacji pozakonstytucyjnej zasady suwerenności narodu, której te działania miały być wyrazem. To powodowało, że parlamentarzyści (szczególnie posłowie czy deputowani) w swoich wystąpieniach traktowali Sejm jako emanację narodu, co wkrótce zostanie potwierdzone w uchwale o przysiędze.

Na gruncie styczniowych uchwał najwyższym organem państwa nie jest już król, jak było w 1815 r., a Sejm, z tym że na plan pierwszy wysunęła się Izba Poselska. Potwierdzeniem tej dominującej pozycji parlamentu były postanowienia uchwały o przysiędze z 8 lutego $1831 \mathrm{r}^{20}$, której art. 2 stwierdzał:

„Nim naród w sejmie obierze króla, wykonaną będzie przysięga sejmowi, naród reprezentującemu; przysięgę takową wykonywać będą duchowni, wojsko, urzędnicy, gminy i miasta, zgoła wszyscy mieszkańcy kraju polskiego".

Z art. 3 wynikało zaś, że ,otwarte będą po województwach, powiatach i miastach księgi” w celu złożenia ,własnoręcznego podpisu wykonującego przysięgę, a to na wieczną pamiątkę odrodzenia się ojczyzny naszej”.

Projekt tej uchwały został odrzucony przez Senat. Na posiedzeniu Izb połączonych w dniu 7 lutego senator Krzysztof Bieńkowski thumaczył, że stało się to m.in. $z$ tego powodu, że „byłoby nielogicznie, aby mandanci przysięgali mandataryuszom, tem bardziej, że raczej w Rządzie, na który przelano władzę królewską, jak w Sejmie jest prawo majestatu”. Odpowiadając, poseł Józef Świrski stwierdził, że prawo składania przysięgi przysługuje „Sejmowi, który jest teraz władzą najwyższą". W celu wyjaśnienia tej sprawy deputowany

${ }^{19}$ Dyaryusz..., t. I, s. 133.

${ }^{20}$ Ibidem, s. 559-561. 
F. Wołowski dodawał: „Sankcya więc królewska i główne atrybucye są przy Izbach, inne zaś atrybucye królewskie tylko z delegacyi Izb na rząd zlane"21.

W sposób zasadniczy tę sytuację krytykował Maurycy Mochnacki:

„Powstanie przed wyruszeniem do boju wdziewało królewską purpurę na swe ramiona, mniemając zapewne, że w tych znakach majestatu poważniej i dzielniej się zetrze z carem. Najjaśniej sze izby kazały sobie na wierność przysięgać narodowi”22.

Tymczasem problem polegał na stworzeniu mechanizmu rządzenia, po to by można skutecznie prowadzić wojnę z Rosją. A z tym było źle, o czym dalej.

Styczniowe uchwały Sejmu można uznać łącznie za nową ustawę konstytucyjną ${ }^{23}$. Władysław Rostocki twierdził, że taki sam charakter miała uchwała o władzy wodza naczelnego z 24 stycznia $^{24}$, z czym należy się zgodzić. Ta konstatacja odnosiłaby się oczywiście do przedmiotu regulacji, a nie jakiejś szczególnej mocy prawnej styczniowych aktów prawnych, które były jej pozbawione. Na konstytucyjny charakter tych uchwał wskazywał także fakt, iż określały one zakres obowiązywania ustawy konstytucyjnej nadanej przez Aleksandra w $1815 \mathrm{r}$.

W efekcie Sejm, ze szczególnym uwzględnieniem roli Izby Poselskiej, stawał się ustrojowym suwerenem ${ }^{25}$, co z kolei dobrze symbolizowały postanowienia lutowej uchwały o przysiędze. Poseł Roman Sołtyk 28 stycznia trafnie zauważył: „My, Sejm, mamy władzę najwyższą, lecz trzeba jej używać z pewną wstrzemięźliwością" 26 , z czym było różnie.

$\mathrm{Z}$ przewagą parlamentu $\mathrm{z}$ pewnością nie mieliśmy do czynienia na gruncie ustawy konstytucyjnej nadanej Królestwu przez Aleksandra w 1815 r., a co było charakterystyczne dla pozycji Sejmu w Ustawie Rządowej z 3 maja $1791 \mathrm{r}$. Trudno rozstrzygnąć, czy rozwiązania ustrojowe z $1831 \mathrm{r}$. stałyby się fundamentem ustroju niepodległego państwa, gdyby wojna z Rosją zakończyła się zwycięstwem Królestwa. Nie ulega jednak wątpliwości, że w takiej sytuacji trudno byłoby pozbawić Sejm uzyskanej przez niego najwyższej pozycji ustrojowej, co zgodne było nie tylko z tradycją szlacheckiego parlamen-

${ }^{21}$ Ibidem, s. 532, 533, 548.

${ }^{22}$ M. Mochnacki, Powstanie narodu polskiego w roku 1830 i 1831, Warszawa 1984, t. II, s. 335.

${ }^{23}$ Również na konstytucję III Republiki Francuskiej złożyły się łącznie trzy ustawy przyjęte przez Zgromadzenie Narodowe w 1875 r.: O organizacji władz publicznych, O organizacji Senatu i O stosunkach między władzami publicznymi. Teksty tych aktów zamieszczone są w: M. Duverger, Constitutions et documents politiques, Paris 1966.

${ }^{24}$ W. Rostocki, Władza Wodzów Naczelnych..., s. 61.

${ }^{25}$ Z. Gołba, Rozwój..., s. 119, przyp. 35 twierdził, że zmiana ustrojowa polegała raczej na „przechwyceniu przez Sejm roli namiestnika władzy królewskiej”.

${ }^{26}$ Dyaryusz..., t. I, s. 342. Leon Dembiński (Moje wspomnienia..., s. 364) stwierdził po latach: „Prawdziwym nieszczęściem dla kraju było ciągłe trwanie Sejmu i przywłaszczanie przez tegoż władzy monarszej”. 
taryzmu, ale dodatkowo uzyskałoby legitymację wynikającą ze skutecznego przewodzenia w walce o niepodległość.

III. Powtórzmy, że nowy kształt aparatu państwowego Królestwa wyznaczała najwyższa pozycja Sejmu. Jednak dla całości ustroju ważne byłoby też określenie miejsca zajmowanego w nim przez władzę wykonawczą oraz Wodza Naczelnego.

Uchwała o władzy naczelnego wodza z 24 stycznia została podjęta właściwie bez dyskusji ${ }^{27}$. W preambule stwierdzano, że istnieje potrzeba ,oznaczenia władzy, jaka naczelnemu wodzowi wojsk polskich powierzoną być ma”. Art. 2 stanowił, że „Kierunek siły zbrojnej, jako też mianowanie dowódców i oficerów aż do stopnia pułkownika włącznie, należą do naczelnego wodza", dodatkowo w jego gestii było „Prawo zawierania układów o zawieszenie broni” (art. 4). Wódz naczelny nie był członkiem rządu, ale zgodnie z art. 10 „mieć będzie głos stanowczy w rządzie w tem, co się rzeczy wojennych dotyczy, a to dopóki tego miejscowe położenie głównej kwatery bez uchybienia działaniom wojennym pozwoli”. Stanisław Barzykowski twierdził, że w świetle tej uchwały „,wódz, był to pan bez żadnego ograniczenia, pan absolutny"28, chociaż mogło odnosić się to raczej do jego stosunków z rządem niż z Sejmem.

Powyższa uchwała nie regulowała, kto i w jakim trybie miał powoływać Wodza Naczelnego, ale chyba zrozumiałe było, że była to kompetencja Sejmu, skoro dwa dni wcześniej został on przezeń powołany; tym samym „Sejm zajmując się bezpośrednio wyborem wodza zaakceptował swoją wolę przejęcia atrybutów władzy królewskiej”’29. Nieco późnej, bo w debacie 28 stycznia, deputowany Konstanty Witkowski mówił, że „wybór nawet Wodza przez obydwie Izby Sejmujące wzmocni zaufanie wojska, bo wybór, przez naród zrobiony, nie może być mylnym". Natomiast poseł Franciszek Sołtyk thumaczył: „Wybór Wodza (...) nigdy do Rządu należeć nie może, bo wódz jest członkiem Rządu; jakże to być może, aby ta sama władza tęż samą wybierać mogła, wybór ten do Sejmu należeć musi”"30.

Znacznie większe problemy były z przyjęciem uchwały o rządzie. $\mathrm{Na}$ wstępie odrzucono zarówno projekt S. Barzykowskiego stworzenia trzyosobowego rządu wyposażonego w kompetencje identyczne jak monarchy w Królestwie Polskim, jak i projekt L. Dembowskiego, który chciał przekazania tych uprawnień w ręce prezesa Rady Ministrów, co przypominałoby rozwiązanie z $1812 \mathrm{r}^{31}$

${ }^{27}$ Dyaryusz..., t. I, s. 167-169. Szerzej o okolicznościach związanych z przyjęciem tej uchwały zob. W. Rostocki, Władza Wodzów Naczelnych..., s. 59-63.

${ }^{28}$ S. Barzykowski, Historya..., t. II, s. 151.

${ }^{29}$ Z. Gołba, Rozwój..., s. 121.

${ }^{30}$ Dyaryusz..., t. I, s. 354, 352.

${ }^{31}$ S. Barzykowski, Historya ..., t. II, s. 129-130. 
W dniu 29 stycznia, po czterech dniach intensywnej (i niekiedy dość chaotycznej) debaty w Izbie Poselskiej, przyjęto uchwałę o rządzie, w istotny sposób modyfikując wstępny projekt tej uchwały. Poczynione zmiany ,jeszcze bardziej wzmacniały jego (Sejmu) władzę, zwłaszcza w sprawach polityki personalnej" 32 .

Rezygnując z proponowanej zawartości art. 1, który brzmiał: „Sprawowanie władzy królewskiej (...) powierza się Rządowi Narodowemu Królestwa Polskiego. Dopełnia on w całej rozciągłości wszelkie działania władzy rządzącej" ${ }^{33}$, doprowadzono do pomniejszenia zakresu władzy rządu na rzecz Sejmu, ale za to nie uchwalono art. 13, powołującego w przypadku limity Sejmu komisję złożoną z członków obu Izb, która „czuwać będzie nad działaniami rządu"34. Zwiększono skład Rządu Narodowego z 3 do 5 członków, przy czym komplet stanowiły 3 osoby ${ }^{35}$. Ponadto rozstrzygnięto, że „Rząd ma być odosobniony od Ministrów, a nie spoczywać w Radzie Ministrów z Prezydującym"36, co stanowiło o powstaniu dualizmu Rząd Narodowy-ministrowie.

Należy jeszcze zwrócić uwagę, że Sejm w uchwale o sposobie początkowania, obradowania, dyskutowania i przyjmowania projektów z 22 stycznia wzmocnił swoją pozycję wobec rządu, przyznając sobie prawo inicjatywy ustawodawczej na równi z rządem, a także ustalając zasadę, że akty prawne przyjęte w obu Izbach sejmowych nie będą wymagały aprobaty rządu, co oznaczało zanik sankcji. Jednak deputowany F. Wołowski, wnosząc projekt tej uchwały, mówił, że „w narodach konstytucyjnych veto rządowi koniecznie należy, aby władza prawodawcza nie stanowiła praw, które by rząd w jego czynnościach krępować miały, lub paraliżować mogły”37.

Wszystko to razem spowodowało, że „Rząd Narodowy otrzymał bardzo ograniczoną „władzę konstytucyjną królewską” („władzę rządzącą”), a więc pośredniczącą między władzą wykonawczą (ministrowie) a ustawodawczą

${ }^{32}$ Z. Gołba, Rozwój..., s. 126.

${ }^{33}$ Dyaryusz..., t. I, s. 254.

${ }^{34}$ Ibidem, s. 255. 28 stycznia deputowany Franciszek Jabłoński mówił: „Art. 13 jest zbyteczny, zawczesny, hańbiący Izbę. Stanowimy Rząd z władzą królewską, obdarzamy go zaufaniem i zaraz stanowimy nad nim nadzór, więc i nad tym nadzorem trzeba by jeszcze nadzór ustanowić, a nad tym ostatnim chyba Pana Boga”. Replikował poseł R. Sołtyk, że ,art. 13 powinien być jak najwyżej, bo jest głową projektu" (s. 342).

${ }^{35}$ Z. Gołba (Rozwój..., s. 222) twierdził, że „kolegialna forma podejmowania decyzji i zagwarantowanie tej kolegialności przez ustalenie kompletu co najmniej trzech osób było śmiałym i trafnym rozwiązaniem konstrukcji naczelnego organu władzy wykonawczej”. Trudno zgodzić się z tym poglądem, szczególnie mając na uwadze toczoną ówcześnie wojnę z Rosją. Znacznie więcej racji miał M. Mochnacki (Powstanie..., s. 317), który uważał, że rząd był to „triumwirat w kwintumwiracie: ta tedy była machina nieodpowiedzialna, z ministrami odpowiedzialnymi”.

${ }^{36}$ Dyaryusz..., t. I, s. 285, 286.

${ }^{37}$ Ibidem, s. 116. 
(którą Sejm zagwarantował sobie bez reszty)"38. Podobnie sądził inny historyk: „Dzieląc atrybucje monarchy między Sejm, wodza i rząd, temu ostatniemu pozostawiono prawa mniej istotne, drugorzędne, szczupło zakreślone"39. Trudno się nie zgodzić z Maurycym Mochnackim: „Któż u nas był władzą najwyższą, rządzącą? Był oczywiście Sejm. Któż miał być władzą wykonawczą? Oto oczywiście Rząd Narodowy, emanacja, wydział Sejmu" ${ }^{\text {"40. Trochę }}$ później S. Barzykowski pisał usprawiedliwiająco, że po tym, jak zabrakło króla, Sejm „musiał w części i jego miejsce zastąpić, i zarazem stać się Sejmem ustawodawczym i być niejako władzą absolutną"41.

IV. Co prawda, uchwała detronizacyjna wyraźnie stanowiła, że formą państwa polskiego jest nadal monarchia, przy czym dysponowanie koroną polską należało do narodu ucieleśnionego przez Sejm, to wydawało się, że ta monarchiczna forma państwa jest za mało określona. Problem ten miała załatwić uchwała o przysiędze z 8 lutego, która została odrzucona przez Senat, a następnie przyjęta przez Izby połączone, o czym już wspominałem.

Na posiedzeniu Izb połączonych senator K. Bieńkowski mówił:

„Oświadczenie formy rządu jest naprzód: przedwczesne, przechodzące mandat teraźniejszego sejmu, który wszystko, co uczynił z prawa konieczności; byłoby więc antycypowaniem władzy i uzurpacyą, gdyby postanowiono to, czego konieczna potrzeba nie wymaga".

Samo określenie „monarchia” jest mało precyzyjne, gdyż „mogłoby nawet dać powód do rozumienia, że Naród polski chce rządu samowładnego, prawem upoważnionego”. I wreszcie, „nie powiedziano, w jakim sejmie wybór króla ma nastąpić. Sejm teraźniejszy nie miałby do tego prawa"42. Zbijał te argumenty głównie deputowany F. Wołowski. Zgodził się, że rzeczywiście ten Sejm nie miał prawa decydowania o tym, do kogo ma należeć korona Królestwa Polskiego, ale może się zdarzyć, iż podjęcie takiej decyzji byłoby koniecznością. Tłumaczył, że „nie ścierpimy ani despotyzmu, ani anarchii, i że przez tron elekcyjny nie będziemy już niepokoić państw europejskich”. Ponadto, „uznajemy monarchię konstytucyjno-reprezentacyjną, chociaż w rzeczy samej nie istnieje w Europie ani wyobrażać sobie można rządu konstytucyjnego, który nie byłby zarazem reprezentacyjnym, gdy w małych

${ }^{38}$ J. Skowronek, Rzad Narodowy, [w:] Powstanie Listopadowe, pod red. W. Zajewskiego, Warszawa 1980, s. 118.

${ }^{39}$ W. Rostocki, Władza Wodzów Naczelnych..., s. 68.

${ }^{40}$ M. Mochnacki, Powstanie..., s. 314.

${ }^{41}$ S. Barzykowski, Historya ..., t. I, s. 149. I dalej: „W naszem przekonaniu (Sejm), za wiele dla siebie zapragnął. (...) Przez to zaś, że brał za wiele, słabym się stawał”.

${ }^{42}$ Dyaryusz..., t. I, s. 532. 
tylko państwach i rzeczypospolitych lud cały dzierżyć może władzę prawodawczą"43.

Ostatecznie uchwała została przyjęta przez Izby połączone z redakcyjnymi tylko poprawkami. Sejm, ,,uznawszy potrzebę oświadczenia przed Europą, jaka forma rządu dla Polski jest najwłaściwszą", w art. 1

„W imieniu narodu oświadcza, iż uznaje monarchię konstytucyjno-reprezentacyjną z prawem następstwa wybrać się mającej rodziny, jako jedyną odpowiadającą potrzebom swoim, że form jej nawet $\mathrm{w}$ tem bezkrólewiu najściślej przestrzegać będzie i nikomu ich bezkarnie przekroczyć nie dozwoli”.

F. Wężyk oceniał, że powyższa uchwała, to akt, który „godnym będzie uwagi potomnych" ${ }^{44}$. Zupełnie inaczej sądził o tym M. Mochnacki:

„Kto ogłasza monarchię, a nie obiera króla, ogłasza konkurs na berło, stręcząc swoim i obcym wab niebezpieczny (...) Czyż nie lepiej było nareszcie posadzić żywego króla na tronie jak larwę królewską? Znak majestatu bez o s o by: cóż to za mądrość polityczna? Wszystkie niedogodności, wszystkie przywary monarchii: utemperowanej bez jednej jej korzyści, be z interesu dynastii: cóż to za loika, co to za rachuba!"

Wniosek końcowy brzmi:

„Ponieważ chciano monarchii, trzeba było więc zaraz obrać króla (...) Król polski (...) była to ostatnia, jak sądzę, kombinacja zbawienna" ${ }^{45}$.

Jak wyglądałaby ta monarchia konstytucyjno-reprezentacyjna, gdyby przyjąc rozwiązania ustrojowe zawarte $\mathrm{w}$ uchwałach ze stycznia i lutego 1831 r.? Sejm w roli najwyższej władzy w państwie, z uzależnionym od siebie rządem i dysponujący w dodatku polską koroną, szybko mógłby doprowadzić do powstania w miejsce monarchii konstytucyjnej czegoś na kształt koronowanej republiki, z czym zresztą mieliśmy już do czynienia w niedawnej przeszłości w Rzeczypospolitej szlacheckiej; rezygnacja z wolnej elekcji władcy na rzecz wyboru dynastii panującej niewiele by tu zmieniała. Trudno zatem się nie zgodzić, że w uchwale z 8 lutego ,najpełniej zrealizowana została idea polskiego sejmowładztwa" 46 .

${ }^{43}$ Ibidem, s. 543-549.

${ }^{44}$ F. Wężyk, Powstanie..., s. 61.

${ }^{45}$ M. Mochnacki, Powstanie..., s. 337. Tak samo S. Barzykowski, Historya..., t. II, s. 169: „Skoro Mikołaj z tronu zepchnięty został, tron ten nie powinien był ani chwilę zostać wakującym. Okrzykowi „Nie ma króla!” powinien towarzyszyć drugi: „Niech żyje król!” taka jest maksyma monarchiczna, takie następstwo konieczne, taka loika polityczna”.

${ }^{46}$ Z. Gołba, Rozwój..., s. 222. 
V. Słabość ustrojowej pozycji władzy wykonawczej była tak oczywista, że musiało to ulec zmianie ${ }^{47}$ - nawet kosztem pewnego uszczuplenia dotychczasowych uprawnień Sejmu.

Pierwszy projekt nowej struktury władzy wykonawczej pochodzi z drugiej połowy kwietnia $1831 \mathrm{r}^{48}$ Ostatecznie 9 czerwca pojawił się w Sejmie projekt uchwały, w ramach którego „Rząd Narodowy (...) powierzony zostaje namiestnikowi Królestwa przez Izby połączone niezwłocznie wybrać się mającemu" (art. 1). Parlament miałby ponadto wybrać prezesa Rady Ministrów, zastępującego namiestnika (art. 2). Zarządzanie Królestwem należałoby do namiestnika i Rady Ministrów, z tym że ministrowie mieliby jedynie głos doradczy, ale zachowano zasadę kontrasygnaty (art. 3). Wódz Naczelny pozbawiony został głosu stanowczego w rządzie (art. 4$)^{49} .14$ czerwca projekt ten został odrzucony przez Sejm ${ }^{50}$.

Kolejną próbę wzmocnienia władzy wykonawczej rozpoczęto od nowelizacji uchwały o władzy naczelnego wodza, co miało miejsce 14 sierpnia $^{51}$. Art. 1 noweli stanowił: „Mianowanie Naczelnego Wodza i odwołanie jego należeć ma odtąd do atrybucyi Rządu Narodowego”. Jednocześnie „Wódz Naczelny przestaje być członkiem Rządu Narodowego" (art. 2). Właściwie wszyscy uczestniczący w dyskusji poparli to stanowisko, wyjątkiem był poseł F. Wężyk: „Jestem za tem, ażeby władza nominowania Naczelnego Wodza przy Sejmie pozostała" 52 .

W dniu 17 sierpnia doszło do przyjęcia noweli uchwały o rządzie ${ }^{53}$; i ta debata nie była szczególnie długa. W gruncie rzeczy nawiązano tu do rozwiązań, jakie pojawiły się w trakcie styczniowej dyskusji w parlamencie ${ }^{54}$. Przede wszystkim nastąpiło odejście od kolegialnego charakteru Rządu Narodowego na rzecz powierzenia rządu Prezesowi Rady Ministrów, powoływanemu przez Izby połączone (art. 1). Ponadto zrezygnowano z rozróżnienia władzy rządowej i władzy wykonawczej, co rodziło dualizm Rząd Narodowy

${ }^{47}$ Sebastian Ziółek (Sejm Królestwa Polskiego..., s. 136) pisał jasno: „Uchwała Sejmu o Rządzie Narodowym została uznana za jedną z najistotniejszych przyczyn późniejszej klęski powstania. Wynikało to $\mathrm{z}$ ustanowienia rządu o skomplikowanej strukturze i pozbawionego silnej władzy wykonawczej oraz powołanie w jego skład Naczelnego Wodza, którego decyzje i ich realizacja były pozbawione bieżącej kontroli zarówno ze strony rządu, jak i Sejmu”.

${ }^{48}$ Ibidem, s. 212-213.

${ }^{49}$ Dyaryusz..., t. IV, s. 243, przypis.

${ }^{50}$ Szerzej o pracach nad tym projektem zob. S. Ziółek, Sejm Królestwa Polskiego..., s. $222-$ -231 .

${ }^{51}$ Dyaryusz..., t. VI, s. 427-428.

${ }^{52}$ Ibidem, s. 406.

${ }^{53}$ Ibidem, s. 454-458.

${ }^{54}$ S. Barzykowski (Historya ..., t. V, s. 158) podnosił, że był to „odnowiony pomysł kasztelana Dembowskiego (...) w komisyach przez Bonawenturę Niemojowskiego popierany, z tą zmianą a w naszem przekonaniu i ulepszeniu, że prezes głos stanowczy, a ministrowie tylko głosy doradcze i kontrasygnowanie były pozostawione". 
- ministrowie. Odtąd „Prezes powołuje 6 ministrów wydziałów rządowych i zastępcę prezesa (...) Sam tylko prezes lub jego zastępca mieć będzie głos stanowczy, a ministrowie zasiadać mają z głosem doradczym. Każde postanowienie prezesa $\mathrm{w}$ imieniu Rządu Narodowego (...) wydane być powinno na radzie i zaświadczone podpisem jednego z ministrów" (art. 2). W art. 3 powtórzona zostaje kompetencja Prezesa do nominowania i odwołania Naczelnego Wodza ${ }^{55}$ oraz prawo ułaskawienia.

Większość dyskutantów zgadzała się z taką zmianą struktury rządu. Protestował jedynie deputowany Jakub Klimontowicz:

„Nie byłem nigdy za jedny m; teraz tem bardziej za nim nie będę, że on sam ma mieć głos stanowczy, a Ministrowie głos tylko doradczy, że on nawet Ministra ma mianować. Jest to to samo, co dyktator z mocą nieograniczoną, a wiemy, co to jest dyktator" 56 .

Z kolei poseł Bonawentura Niemojowski przypomniał, że on już w styczniu proponował taką właśnie strukturę rządu, co wtedy zostało przez Izbę zignorowane ${ }^{57}$.

W noweli uchwały o rządzie z 17 sierpnia Sejm nie zapomniał o podkreśleniu swojej najwyższej pozycji w państwie. $Z$ art. 4 wynikało, że prawo „wydawania wojny, zawierania traktatów i umów wszelkich, przy izbach połączonych zostają”. Ponadto „Izby sejmowe odtąd aż do oswobodzenia stolicy pracować będą w połączeniu, a same tylko w każdym razie zalimitować lub rozwiązać się mogą" (art. 5).

W sierpniu 1831 r. doszło do zmiany zarówno uchwały o Wodzu Naczelnym, jak i rządzie. W konsekwencji doprowadziło to do skupienia władzy wykonawczej w osobie prezesa Rządu Narodowego, wyeliminowania dualizmu rząd-ministrowie i podporządkowania Wodza Naczelnego prezesowi rządu ${ }^{58}$. Ale i tak Sejm utrzymał swoją najwyższą pozycję w aparacie państwowym Królestwa, gdyż do niego należała decyzja o zawieraniu traktatów i możliwość zalimitowania swoich obrad bądź rozwiązania się. Cokolwiek jednak powiedzieć, w strukturze władzy publicznej zaczynał się zwrot w kierunku stworzenia równowagi między parlamentem a władzą wykonawczą, chociaż trudno mówić, że proces ten został zakończony.

55 Słuszny wniosek W. Rostockiego, Władza Wodzów Naczelnych..., s. 158: „Prawo mianowania i odwołania wodza przesądzało, w razie sporu kompetencyjnego, dotyczącego naczelnego kierownictwa sprawami wojskowymi, zwycięstwo na rzecz prezesa”.

${ }^{56}$ Dyaryusz..., t. VI, s. 450.

${ }^{57}$ Ibidem, s. 451.

${ }^{58}$ Trafne podsumowanie Z. Gołby, Rozwój..., s. 200: „Nowa uchwała była aktem odwrotu od zasady kolegialności, która stanowiła podstawę działania dotychczasowego rządu. Prezes Rady Ministrów sprawował władzę wykonawczą samodzielnie". 
Raz jeszcze, już po opuszczeniu Warszawy, Sejm dokonał nowelizacji uchwał o Wodzu Naczelnym i Rządzie Narodowym, co zostało przeprowadzone ,jak gdyby w trybie doraźnym"59. 23 września w Płocku Izby przyjęły uchwałę, której art. 2 stanowił: „Władza, Prezesowi Rządu Narodowego uchwałą z d. 17 sierpnia rb. nadana, zlewa się na Wodza Naczelnego", przy czym teraz jest on wybierany ,większością głosów Izb połączonych” (art. 3$)^{60}$. Nic nie mówiło się w uchwale o uprawnieniach Sejmu, ale nie ma wątpliwości, że dotychczasowe pozostały. Na koniec w art. 5 podkreślono: „Uchwała niniejsza ma moc obowiązującą dopóty, dopóki Sejm inaczej nie postanowi”; wskazywałoby to nadzwyczajny charakter tego rozwiązania prawnego.

„Koncentracja obu władz w jednym ręku była właściwie przywróceniem władzy dyktatorskiej, aczkolwiek unikano tego określenia”. Mimo to „Sejm za wszelką cenę pragnął zachować dotychczasowe zwierzchnictwo i do końca decydować o losach powstania"61. Słowem, mieliśmy tu do czynienia z czymś w rodzaju dyktatury, chociaż o charakterze konstytucyjnym.

Gen. Jan Nepomucen Umiński, wybrany 23 września na Wodza Naczelnego, odmówił przyjęcia tak olbrzymiej władzy i doszło znowu do rozdzielenia władzy cywilnej i wojskowej ${ }^{62}$. Dosłownie ostatni zapis w Diariuszu głosi, iż Izby zgodziły się, żeby Rząd mógł zmienić Wodza Naczelnego - mimo że wybrał go Sejm ${ }^{63}$.

Pod koniec września 1831 r. spełniło się marzenie M. Mochnackiego; powstała pozakonstytucyjna żołnierska dyktatura ${ }^{64}$, na czele której stanął gen. Maciej Rybiński, ostatni Wódz Naczelny ${ }^{65}$. Po opuszczeniu Królestwa przez rząd i Sejm „Ostatni wódz naczelny skupiał teraz dyktatorską, nieograniczoną przez żaden czynnik, najwyższą władzę cywilną i wojskową”. I dalej: „Na placu zostaje faktyczny dyktator Rybiński, który wkrótce $5 \mathrm{X}$ przejdzie granicę pruską z 20-tysięczną armią. (...) Wódz naczelny - faktyczny dyktator wiódł na tułaczkę resztki wojska polskiego" "66. To nie miało jednak nic wspólnego z tym, czego sobie życzył znany radykał.

${ }^{59}$ Ibidem, s. 216.

${ }^{60}$ Dyaryusz..., t. VI, s. 686-687, 688. Tak pisał o tej uchwale S. Barzykowski, Historya..., t. V, s. 362: „Już władz, ani sejmów, ani rządów cywilnych nie było potrzeba, tylko męża wielkiego serca i ostrego pałasza, aby cała władza cywilna i militarna w jednej ręce, w ręce wodza złożona być mogła"

${ }^{61}$ Z. Gołba, Rozwój..., s. 217.

${ }^{62}$ Dyaryusz..., t. VI, s. 695, 697.

${ }^{63}$ Ibidem, s. 708-709.

64 Obszerne uzasadnienie stanowiska o konieczności ustanowienia dyktatury w czasie wojny z Rosją zob. M. Mochnacki, Powstanie..., t. II, s. 149-156; podobną argumentację przedstawia S. Barzykowski, Historya..., t. II, s. 127. Dobrą analizę stanowiska M. Mochnackiego zawiera praca B. Łagowskiego, Filozofia polityczna Maurycego Mochnackiego, Kraków 1981, rozdz. V i VI.

65 S. Barzykowski, Historya..., t. V, s. 368.

${ }^{66}$ W. Rostocki, Władza Wodzów Naczelnych..., s. 186. Bardzo negatywnie o tym końcowym epizodzie wojny z Rosją wypowiedział się S. Barzykowski, Historya..., t. V, s. 382: „Wprawdzie 
Zmiany z sierpnia i września 1831 r. uchwał o Wodzu Naczelnym i rządzie szły w kierunku wytworzenia silnej władzy wykonawczej, ale pojawiły się zbyt późno, by mogły wpłynąć na los Królestwa walczącego z Rosją o niepodległość; być może inaczej sytuacja wyglądałyby, gdyby tego rodzaju decyzje zapadły w styczniu $1831 \mathrm{r}$. Jednak nawet sierpniowe i wrześniowe nowele uchwał o Wodzu Naczelnym i rządzie, uszczuplając najwyższą pozycję, jaką posiadał Sejm, ostatecznie pozostawiały w gestii parlamentu decyzje o wojnie i pokoju, także jedynie Izby połączone były władne dokonać limity swoich obrad bądź rozwiązać się. Jak fatalny miało to wpływ na los państwa, mogliśmy przekonać się na początku września 1831 r., kiedy została zaprzepaszczona ostatnia szansa uratowania bytu Królestwa Polskiego, choć tylko w kształcie sprzed nocy listopadowej ${ }^{67}$.

VI. Zmiany konstytucji Królestwa Polskiego, dokonane przez parlament głównie w styczniu 1831 r., wiodły do ukształtowania ustroju z suwerennym Sejmem w roli głównej. Przypominałoby to w zasadniczy sposób rozwiązania, z jakimi mieliśmy do czynienia na gruncie Ustawy Rządowej z 3 maja 1791 r., aczkolwiek trudno twierdzić, żeby było to świadome naśladownictwo. Dodatkowo pozycja ustrojowa parlamentu wzmocniła się przez fakt ogłoszenia wakującego tronu i podziału uprawnień monarszych, głównie na rzecz Sejmu.

W 1791 r., zrywając ostatecznie z istnieniem trzech równorzędnych stanów sejmujących (Izby Poselskiej, Senatu i monarchy), na pierwszy plan wysunięto nawet nie obie Izby łącznie, co właściwie Izbę Poselską ${ }^{68}$, stąd trudno było mówić o bikameralizmie. Dokładnie z takim schematem mieliśmy do czynienia w $1831 \mathrm{r}$.

Od suwerennego Sejmu w pełni zależna była też władza wykonawcza. Na gruncie Ustawy Rządowej z 3 maja król nie uczestniczył w ustawodawstwie, nie był najwyższym sędzią, Straż Praw była jedynie radą królewską, nie zaś współczesną radą ministrów, a właściwy zarząd państwa należał do kolegialnych komisji ${ }^{69}$. Strukturalnie nieco inaczej, ale w sensie funkcjonalnym tak

nie dostawał jenerał Rybiński buławy wśród szczęśliwego położenia, ale zaiste nieudolniej i nieszczęśliwiej piastować jej już nie można było".

${ }^{67}$ Szerszej analizy tych wydarzeń dokonuje L. Mażewski, Próba ratowania Królestwa Polskiego. O prawnopolitycznych aspektach negocjacji polsko-rosyjskich we wrześniu 1831 r., „Czasopismo Prawno-Historyczne", 2013, z. 1.

${ }^{68}$ B. Leśnodorski, Dzieło Sejmu Czteroletniego (1788-1792), Wrocław 1951, s. 285: „Szala wpływów przeważała na rzecz izby poselskiej”; podobny pogląd szeroko uzasadnia Z. Szcząska, Ustawa Rządowa z 1791 r., [w:] Konstytucje Polski, pod red. M. Kallasa, Warszawa 1990, t. I, rozdz. 1.5.2.2 oraz rozdz. 1.5.2.3.

${ }^{69}$ Tak B. Leśnodorski, Dzieło..., część III, rozdz. III; Z. Szcząska, Ustawa Rządowa..., s. 72 byłby raczej gotów uznać, że „Tak jak »rząd« kraju należał do króla i Straży Praw, tak »administracja« (z wyjątkiem spraw zagranicznych i sprawiedliwości) należała do komisji rządowych zwanych wielkimi (policji, skarbu, wojska i edukacji) oraz komisji porządkowych i samorządów miejskich”. 
samo, rzeczy miały się na gruncie uchwał z początku 1831 r. Rozdrobniona i dysfunkcjonalna władza wykonawcza (o czym decydowała kolegialność działania Rządu Narodowego, istnienie dualizmu Rząd Narodowy-ministrowie, niezależność Wodza Naczelnego od rządu) całkowicie zależna była od Sejmu; ten stan rzeczy pogłębiało bezkrólewie.

Po pewnym czasie zaczęło budzić to sprzeciw. Na gruncie projektu uchwały o rządzie z 9 czerwca mieliśmy do czynienia nie tylko z próbą powrotu do instytucji namiestnika, ale także z recepcją rozwiązań z konstytucji z $1815 \mathrm{r}$. w zakresie stosunków między namiestnikiem a Radą Administracyjną ${ }^{70}$. Nie wiadomo, dlaczego pojawił się tu prezes Rady Ministrów, ustanawiany w taki sam sposób jak namiestnik, co mogło prowadzić ponownie do dysfunkcjonalności systemu władzy wykonawczej.

Sytuacja zaczyna się zmieniać wraz z uzależnieniem Wodza Naczelnego od rządu i wprowadzeniem nowej struktury Rządu Narodowego, co miało miejsce w sierpniu $1831 \mathrm{r}$. Oznaczało to rezygnację z dalszego utrzymywania schematu, jaki dominował w zakresie stosunków między Sejmem a organami władzy wykonawczej w $1791 \mathrm{r}$.

Nikt z uczestników debaty w dniu 17 sierpnia nie podniósł, że zaproponowany model Rządu Narodowego, to nic innego jak powrót do Rady Administracyjnej w sytuacji, gdy monarcha skorzystał ze swego prawa i mianował namiestnika; prezes Rządu Narodowego to właśnie namiestnik w Radzie Administracyjnej ${ }^{71}$.

Rozwiązania z 17 sierpnia nie tylko zrywały z propozycjami zawartymi w Ustawie Rządowej z 3 maja, ale również naruszały ustrojową tradycję Rzeczypospolitej szlacheckiej, której ważną cechą było istnienie rozproszenia władzy wykonawczej w imię obrony wolności szlachty. Rzeczy zaczęły się zmieniać dopiero od momentu powstania Rady Nieustającej w 1775 r. ${ }^{72}$; oczywistym zaś odstępstwem od takiej struktury władzy wykonawczej stała się dyktatura Tadeusza Kościuszki w 1794 r., choć i tu zwraca się uwagę na skorzystanie $\mathrm{z}$ rodzimego dorobku ${ }^{73}$, a nie sięganie do tradycji rzymskiej dyktatury.

W uchwale z 23 września, przekazującej Wodzowi Naczelnemu również władzę cywilną, uczyniono krok dalej, niż przewidywała konstytucja Królestwa Polskiego, której rozwiązanie typu konstytucyjnej dyktatury nie było

${ }^{70} \mathrm{O}$ powiązaniu obu tych organach w: L. Mażewski, Monarcha $\mathrm{i}$ namiestnik $w$ Konstytucji Królestwa Polskiego z 1815 r., „Studia Prawnicze KUL”, 2012, nr 4, s. 76-77.

${ }^{71}$ Po latach zwrócił na to uwagę L. Dembowski, Moje wspomnienia..., s. 361.

${ }^{72}$ Por. W. Konopczyński, Geneza i ustanowienie Rady Nieustającej, Kraków 1917.

${ }^{73}$ Wojciech Bartel (Ustrój władz cywilnych powstania kościuszkowskiego, Wrocław 1959, s. 238) za Joachimem Lelewelem wskazywał, że „Instytucja naczelnika była na pozór nieznana w dziejach ustroju Polski. Bliższa jej analiza pozwala stwierdzić, że wyrasta ona z rodzimej tradycji prawno-ustrojowej. (...) była ona syntezą władzy marszałka konfederackiego i regimentarza”. 
znane. Mimowolnie nawiązano tu do pozycji wicekróla de facto, jaką miał Konstanty w guberniach litewsko-ruskich za życia Aleksandra ${ }^{74}$, chociaż źródłem władzy wielkiego księcia nie była wola Sejmu.

Zatem ustrój Królestwa Polskiego, ukształtowany przez Sejm w styczniulutym 1831 r., w istotny sposób odwzorowywał rozwiązania z 1791 r., aczkolwiek czyniono to mimowolnie. Od sierpniowych nowel uchwał o Wodzu Naczelnym i rządzie mamy do czynienia z odwrotem od schematu dominującego w Ustawie Rządowej z 3 maja w zakresie stosunków między Sejmem a organami władzy wykonawczej, ale nie co do pozycji Izby Poselskiej; sięga się do rozwiązań z konstytucji z 1815 r. odnośnie do namiestnika i Rady Administracyjnej. Jeszcze dalej poszli twórcy uchwały z 23 września, przekazującej Wodzowi Naczelnemu również władzę cywilną. Takie uprawnienia posiadał jedynie Konstanty w guberniach litewsko-ruskich za życia Aleksandra, ale nie tyczyło to Królestwa.

Zmiany konstytucji Królestwa Polskiego, dokonane przez Sejm w styczniu 1831 r., wiodły do ukształtowania ustroju z suwerennym Sejmem na czele, a właściwie główną rolę odgrywała Izba Poselska, co przypominało w zasadniczy sposób rozwiązania, z jakimi mieliśmy do czynienia na gruncie Ustawy Rządowej z 3 maja 1791 r. Pozycja ustrojowa parlamentu dodatkowo wzmocniła się przez fakt wakującego tronu i podział uprawnień monarszych, głównie na rzecz Sejmu.

Pod wpływem suwerennego Sejmu w pełni pozostawała też władza wykonawcza. Na gruncie uchwał z początku 1831 r. rozdrobniona i dysfunkcjonalna władza wykonawcza (na co składała się kolegialność działania Rządu Narodowego, istnienie dualizmu Rząd Narodowy-ministrowie oraz niezależność Wodza Naczelnego od rządu) całkowicie zależna była od Sejmu; ten stan rzeczy pogłębiało bezkrólewie.

Rozwiązania z 17 sierpnia w zakresie struktury i sposobu funkcjonowania Rządu Narodowego nie tylko odrzucały wpływ Ustawy Rządowej z 3 maja, ale w ogóle naruszały ustrojową tradycję Rzeczypospolitej szlacheckiej, cechującą się rozproszeniem władzy wykonawczej, chociaż od chwili powstania Rady Nieustającej w 1775 r. zaczynało się to zmieniać. Sięgnięcie do rozwiązań z konstytucji z 1815 r. odnośnie do namiestnika i Rady Administracyjnej w sierpniowej noweli uchwały o rządzie było oczywiste. Jeszcze dalej poszli twórcy uchwały z 23 września, przekazującej Wodzowi Naczelnemu również

${ }^{74}$ Por. L. Mażewski, B. Szlachta, W. Książę Konstanty jako wicekról de facto?, [w:] System polityczny, prawo i konstytucja Królestwa Polskiego 1815-1830. W przededniu dwusetnej rocznicy powstania unii rosyjsko-polskiej, pod red. L. Mażewskiego, Warszawa 2013, s. 123-125. 
władzę cywilną; w ten sposób uczyniono krok dalej, niż przewidywała konstytucja Królestwa Polskiego, której rozwiązanie typu konstytucyjnej dyktatury nie było znane. Ostatecznie okaże się, że beneficjentem tych rozwiązań ustrojowopolitycznych będzie feldmarszałek Iwan Paskiewicz jako namiestnik Królestwa po $1831 \mathrm{r}^{75}$

\footnotetext{
${ }^{75}$ T. Demidowicz, Statut organiczny z 1832 r., [w:] Konstytucje Polski, s. 297, 301.
} 